\title{
Perbandingan Efektivitas Cefazolin dan Ceftriaxone Sebagai Antibiotik Profilaksis Bedah Ortopedi Open Reduction Internal Fixation (ORIF) Fraktur Tertutup
}

\author{
Nurul Latifah ${ }^{1 *}$, Tri Murti Andayani² ${ }^{2}$ dan Zullies Ikawati² \\ ${ }^{1}$ Magister Farmasi Klinik, Fakultas Farmasi, Universitas Gadjah Mada, Sekip Utara, Yogyakarta, Indonesia, \\ 55281. \\ ${ }^{2}$ Departemen Farmakologi \& Farmasi Klinik, Fakultas Farmasi, Universitas Gadjah Mada, Sekip Utara, \\ Yogyakarta, Indonesia, 55281. \\ *email korespondensi: nurul.latifah.apt@gmail.com \\ Received 30 June 2021, Accepted 22 September 2021, Published 15 November 2021
}

\begin{abstract}
Abstrak: Infeksi daerah operasi (IDO) merupakan infeksi yang terjadi hingga 30 hari setelah operasi atau satu tahun setelah operasi pada pasien yang menerima implan dan mempengaruhi sayatan atau jaringan dalam di lokasi operasi. Sefalosporin golongan pertama yaitu cefazolin merupakan antibiotik pilihan sebagai proflaksis bedah karena merupakan antibiotik spektrum luas, memiliki profil farmakokinetik yang baik, angka kejadian efek samping yang kecil, serta harga relatif murah. Pada praktek klinis, ceftriaxone banyak digunakan karena merupakan antibiotik yang lebih murah dibanding cefazolin. Tujuan penelitian ini adalah untuk mengetahui efektivitas dan keamanan cefazolin dibandingkan dengan ceftriaxone sebagai antibiotik profilaksis pasien bedah ortopedi Open Reduction Internal Fixation (ORIF) fraktur tertutup. Penelitian ini merupakan penelitian observasional analitik dengan rancangan kohort retrospektif dari rekam medis pasien yang menjalani ORIF fraktur tertutup periode 1 Januari hingga 31 Desember 2020 di sebuah rumah sakit swasta tipe B di Yogyakarta. Luaran klinis yang diamati dalam penelitian ini adalah kejadian IDO dan kejadian efek samping selama 90 hari sejak pasien dilakukan prosedur bedah. Terdapat 59 pasien yang menjalani ORIF yang masuk kriteria inklusi pada penelitian ini yang terbagi mejadi dua kelompok yaitu pasien yang mendapat antibiotik profilaksis cefazolin $(n=25)$ dan ceftriaxone $(n=34)$. Hasil dari penelitian ini menunjukkan bahwa angka kejadian IDO pada pasien yang menjalani ORIF fraktur tertutup sebesar 5,08\% dari total subjek atau 8,82\% dari yang diberikan ceftriaxone dan $0 \%$ dari pasien yang diberikan cefazolin. Perbedaan probabilitas kejadian IDO pada pemberian ceftriaxone sebagai antibiotik profilaksis tidak berbeda bermakna dengan pemberian cefazolin $(\mathrm{RR}=1,097$; $95 \% \mathrm{CI}=0,988-1,218 ; \mathrm{p}=0,064)$.
\end{abstract}

Kata kunci: antibiotik profilaksis; fraktur tertutup; IDO; ORIF

Abstract. Comparing Effectivity of Cefazolin and Ceftriaxone for Antibiotic Prophylaxis for Orthopedic Surgery of Open Reduction Internal Fixation (ORIF) in Close Fracture Patient. Surgical site infection (IDO) is an infection that occurs up to 30 days after surgery or one year after surgery in a patient receiving an implant and affects the incision or deep tissue at the surgical site. The first class of cephalosporins, namely cefazolin, is the antibiotic of choice for surgical prophylaxis because it is a broad-spectrum antibiotic, has a good pharmacokinetic profile, has a small incidence of side effects, and is relatively inexpensive. In clinical practice, ceftriaxone is widely used because it is a cheaper antibiotic than cefazolin. The purpose of this study was to determine the effectiveness and safety of cefazolin compared to ceftriaxone as a prophylactic antibiotic for closed fracture orthopedic Open Reduction Internal Fixation (ORIF) patients. This study was an analytic observational study with a retrospective cohort design from the medical records of patients undergoing closed fracture ORIF from January 1 to December 
31, 2020 at a private type B hospital in Yogyakarta. The clinical outcomes observed in this study were the incidence of SSI and the incidence of side effects during 90 days after the patient underwent the surgical procedure. There were 59 patients undergoing ORIF who met the inclusion criteria in this study which were divided into two groups, namely patients who received prophylactic antibiotics cefazolin $(n=25)$ and ceftriaxone $(n=34)$. The results of this study showed that the incidence of SSI in patients undergoing closed fracture ORIF was $5.08 \%$ of the total subjects or $8.82 \%$ of those who were given ceftriaxone and $0 \%$ of patients who were given cefazolin. The difference in the probability of the incidence of SSI on the administration of ceftriaxone as a prophylactic antibiotic was not significantly different from the administration of cefazolin $(\mathrm{RR}=1,097 ; 95 \% \mathrm{CI}=0,988-1,218 ; \mathrm{p}=0.064)$.

Keywords: closed fracture; ORIF; prophylactic antibiotic; surgical site infection

\section{Pendahuluan}

Healthcare-associated Infections (HAIs) atau infeksi yang didapatkan pasien ketika mendapatkan layanan kesehatan merupakan kejadian tidak diharapkan yang paling sering terjadi dan berpengaruh pada keselamatan pasien di seluruh dunia (WHO, 2016). Infeksi daerah operasi (IDO) menyebabkan lebih dari 30\% HAIs dan terjadi pada 1,9-2,7\% dari seluruh pasien operasi. IDO di negara maju, didiagnosis lebih dari 500.000 pasien per tahun dan diperkirakan 8000 orang diantaranya meninggal. Dampak klinik dan finansial secara signifikan muncul akibat terjadinya IDO (Najjar \& Smink, 2015).

Infeksi daerah operasi (IDO) merupakan infeksi yang terjadi hingga 30 hari setelah operasi atau hingga satu tahun setelah operasi pada pasien yang menerima implan dan mempengaruhi baik sayatan atau jaringan dalam di lokasi operasi (Al-Mulhim et al., 2014). Studi yang dilakukan oleh WHO menunjukkan bahwa selain ICU, bangsal bedah akut dan bedah ortopedi merupakan bangsal yang terdapat paling banyak pasien yang mengalami infeksi nosokomial (Girard et al., 2002). Fiksasi internal pada fraktur tertutup merupakan salah satu pembedahan tulang yang memiliki risiko tinggi karena melibatkan pemasangan implan dari material prostetik yang dapat menjadi sumber infeksi (Trampuz \& Widmer, 2006). Angka kejadian IDO setelah pembedahan fraktur tertutup berkisar 1 hingga 4\% (Gans et al., 2017).

Sumber mikroorganisme patogen dari IDO dapat berasal dari endogen maupun eksogen. Faktor endogen paling besar adalah bakteri dari kulit, membran mukosa atau rongga dalam (Bandalović et al., 2015). Bakteri yang paling banyak ditemukan penyebab IDO pada bedah ortopedi diantaranya adalah Staphylococcus aureus, coagulase-negative staphylococci, dan bakteri gram negatif (Li et al., 2013).

Pemilihan antibiotik profilaksis yang tepat dapat melindungi pasien dari infeksi pasca operasi dengan mengurangi kemungkinan jumlah bakteri yang menginfeksi dari pasien maupun lingkungan ruang bedah pada saat operasi (Najjar \& Smink, 2015). Sefalosporin merupakan jenis antibiotik yang paling umum diresepkan karena merupakan antibiotik spektrum luas yang 
efektif sebagai anti Staphylococcus, memiliki profil farmakokinetik yang baik, angka kejadian efek samping yang kecil, serta harga yang relatif murah (Bandalović et al., 2015). Pada kasus bedah ortopedi, sefalosporin generasi pertama seperti cefazolin atau generasi kedua seperti cefuroxime merupakan pilihan yang direkomendasikan (Trampuz \& Widmer, 2006). Penelitian yang dilakukan di sebuah rumah sakit di Jakarta menunjukkan bahwa pada tahun 2012 antibiotik profilaksis yang paling banyak digunakan $(87,8 \%)$ pada kasus ortopedi adalah ceftriaxone (Radji et al., 2014). Ceftriaxone memiliki harga yang lebih murah dibandingkan cefazolin serta belum terdapat penelitian sebelumnya yang membandingkan antara cefazolin dan ceftriaxone sehingga ceftriaxone masih banyak digunakan pada praktek klinis sebagai antibiotik profilaksis bedah ortopedi. Penelitian ini bertujuan untuk mengetahui efektivitas dan keamanan cefazolin dibandingkan dengan ceftriaxone sebagai antibiotik profilaksis pasien bedah ortopedi Open Reduction Internal Fixation (ORIF) fraktur tertutup. Hasil penelitian ini diharapkan dapat menjadi pertimbangan bagi klinisi dalam memilih antibiotik profilaksis.

\section{Metode}

\subsection{Rancangan penelitian}

Penelitian ini adalah jenis penelitian observasional analitik dengan rancangan kohort retrospektif yang melibatkan pasien yang menjalani bedah ortopedi Open Reduction Internal Fixation (ORIF) fraktur tertutup pada periode 1 Januari hingga 31 Desember 2020 di sebuah rumah sakit swasta tipe B di Yogyakarta. Luaran klinis yang diamati dalam penelitian ini adalah kejadian IDO dan kejadian efek samping. Pengamatan dilakukan selama 90 hari sejak pasien dilakukan prosedur bedah. Penelitian ini telah disetujui oleh Komite Etik rumah sakit tempat penelitian dengan nomor 0023/KT.7.4/IX/2020.

\subsection{Subjek penelitian}

Subjek yang digunakan dalam penelitian ini yaitu pasien yang memenuhi kriteria inklusi yaitu pasien fraktur tertutup yang menjalani bedah ortopedi Open Reduction Internal Fixation (ORIF) dan mendapat antibiotik profilaksis cefazolin atau ceftriaxone. Pasien yang didiagnosis infeksi sebelum dilakukan pembedahan, menerima terapi lain dengan antibiotik selain cefazolin atau ceftriaxone sebelum pembedahan, mendapat terapi cefazolin dan ceftriaxone dalam satu periode perawatan, diketahui memiliki status nutrisi yang buruk yaitu albumin $<3,4 \mathrm{mg} / \mathrm{dL}$, memiliki penyakit penyerta HIV, keganasan, covid-19, meninggal, tidak kontrol, dan data rekam medis tidak lengkap dieksklusi dari penelitian ini. Jumlah sampel minimal yang dibutuhkan pada penelitian ini dihitung dengan rumus besar sampel untuk uji hipotesis beda proporsi dua populasi (persamaan 1). 
Penelitan pendahuluan yang dilakukan mendapatkan nilai p1 sebesar 0 dan p2 sebesar 0,3, sehingga jumlah sampel minimal yang dibutuhkan adalah 34 subjek pada masing-masing kelompok.

$$
n=\frac{(Z \alpha / 2 \sqrt[2]{2 \overline{p q}}+Z \beta \sqrt[2]{p 1 q 1+p 2 q 2})^{2}}{(p 1-p 2)^{2}}
$$

Persamaan 1. Rumus uji hipotesis beda proporsi dua populasi. Keterangan: $n=$ jumlah sampel pada masing-masing kelompok; $\mathrm{Z}_{\alpha / 2}=$ adalah nilai distribusi normal baku pada tingkat kemaknaan $\alpha=0,05$ yaitu 1,$96 ; Z_{\beta}=$ adalah nilai distribusi normal baku pada tingkat kemaknaan $\beta$; power of test $=80 \%$, yaitu 0,$842 ; \mathrm{p} 1=$ proporsi IDO pada kelompok pertama (kelompok cefazolin); p2 = proporsi IDO pada kelompok kedua (kelompok ceftriaxone); $\mathrm{q} 1=1-\mathrm{p} 1 ; \mathrm{q} 2=1-\mathrm{p} 2 ; \overline{p q}=$ rata-rata nilai $\mathrm{p}$ dikalikan rata-rata nilai $\mathrm{q}$.

\subsection{Sumber data}

Sumber data penelitian yang digunakan adalah lembar rekam medis dan rekam medis elektronik pasien. Data yang diambil adalah identitas pasien, riwayat pasien, ASA score, diagnosis operasi, hasil pemeriksaan penunjang, penggunaan antibiotik profilaksis, pemantauan infeksi pada daerah operasi, dan kejadian efek samping antibiotik profilaksis selama 90 hari sejak pasien rawat inap untuk menjalani ORIF hingga pasien menjalani rawat jalan.

\subsection{Analisis data}

Analisis efektivitas antibiotik profilaksis dilihat dari perbandingan probabilitas kejadian IDO. Parameter yang menunjukkan bahwa pasien tersebut mengalami IDO yaitu setidaknya mengalami salah satu dari kriteria sebagai berikut : (1) adanya diagnosis yang menyatakan terjadi infeksi luka operasi atau dehisiensi luka operasi dari dokter spesialis bedah atau dokter yang hadir merawat pasien setelah menjalani prosedur operasi; (2) terdapat nanah atau pus yang mengalir dari luka operasi; (3) adanya hasil pemeriksaan mikrobiologi; (4) terdapat salah satu dari tanda dan gejala infeksi seperti nyeri atau tenderness, pembengkakan lokal, kemerahan atau panas, dan demam $\left(>38^{\circ} \mathrm{C}\right)$ (Singh et al., 2014).

Analisis deskriptif dilakukan untuk menganalisis karakteristik subjek penelitian dan karakteristik penggunaan antibiotik profilaksis. Data karakteristik umum pasien dan karakteristik penggunaan antibiotik profilaksis disajikan dalam persentase (\%). Perbedaan proporsi IDO dan kejadian efek samping di antara dua kelompok dianalisis menggunakan uji bivariat Fisher's Exact Test dengan interval kepercayaan (CI) 95\%. Keamanan antibitoik profilaksis tidak dilakukan analisis dikarenakan tidak ditemukan adanya kejadian efek samping pada dua kelompok uji. Uji bivariat Fisher's Exact Test juga dilakukan untuk menganalisis hubungan antara faktor risiko dengan kejadian IDO, diantaranya jenis kelamin, usia, ASA score, penyakit penyerta, durasi operasi, lama rawat inap sebelum operasi, dan waktu 
pemberian antibiotik profilaksis. Variabel dengan nilai $\mathrm{p}<0,25$ dianalisis dengan uji multivariat regresi logistik sederhana. Hubungan disimpulkan bermakna jika nilai $\mathrm{p}<0,05$.

\section{Hasil dan Pembahasan}

\subsection{Karakteristik subjek penelitian}

Jumlah sampel pada penelitian ini 59 pasien yang terdiri dari 25 pasien yang mendapat antibiotik profilaksis cefazolin dan 34 pasien mendapat ceftriaxone. Pasien yang harus dieksklusi disebabkan karena pasien menerima kedua jenis antibiotik dalam satu periode perawatan, menerima antibiotik kombinasi untuk profilaksis, pasien hemodialisa, pasien yang dicurigai covid-19, tidak kontrol, dan pasien meninggal.

Tabel 1. Karakteristik pasien Open Reduction Internal Fixation (ORIF) fraktur tertutup di RS PKU Muhammadiyah Yogyakarta tahun 2020.

\begin{tabular}{ccc}
\hline \multirow{2}{*}{ Karakteristik pasien } & \multicolumn{2}{c}{ Jumlah pasien (\%) } \\
\cline { 2 - 3 } Jenis kelamin & Cefazolin (n=25) & Ceftriaxone (n=34) \\
Laki-laki & $15(60)$ & $15(44,1)$ \\
Perempuan & $10(40)$ & $19(55,9)$ \\
Usia & & \\
$<18$ tahun & $6(24)$ & $1(2,9)$ \\
$18-59$ tahun & $14(56)$ & $24(70,6)$ \\
$\geq 60$ tahun & $5(20)$ & $9(26,5)$ \\
Komorbiditas & & \\
Tidak Ada & $22(88)$ & $22(64,7)$ \\
Ada & $3(12)$ & $12(35,3)$ \\
Skor ASA & & \\
$<3$ & $25(100)$ & $33(97,1)$ \\
$\geq 3$ & 0 & $1(2,9)$ \\
Lokasi Fraktur & & $2(5,9)$ \\
Clavicula & $2(8)$ & $7(20,6)$ \\
Humeri & $2(8)$ & $11(32,4)$ \\
Radius & $8(32)$ & $1(2,9)$ \\
Metacarpal & 0 & $3(8,8)$ \\
Phalanx & $2(8)$ & $6(17,6)$ \\
Femur & $3(12)$ & $2(5,9)$ \\
Tibia & $3(12)$ & $1(2,9)$ \\
Fibula & 0 & 0 \\
Maleolus & $1(4)$ & $1(2,9)$ \\
Metatarsal & $2(8)$ & 0 \\
Calcaneus & $1(4)$ &
\end{tabular}

Data karakteristik umum pasien disajikan pada Tabel 1. Tidak terdapat perbedaan jumlah yang bermakna antara pasien laki-laki dan perempuan baik itu pada kelompok cefazolin (15\% dan $10 \%$ ) maupun ceftriaxone (15\% dan 19\%). Subjek paling banyak adalah pada kelompok usia dewasa 18-59 tahun. Penelitian yang dilakukan di Swedia pada tahun 2015-2018 yang melibatkan 23,917 pasien yang mengalami fraktur, didapatkan rata-rata usia pasien yang 
mengalami fraktur adalah pada usia rentang 16-105 tahun dengan rata-rata 57,9 tahun (Bergh, 2021). Kelompok usia muda lebih banyak melakukan aktivitas yang berat dibandingkan usia tua. Aktivitas masyarakat usia muda di luar rumah cukup tinggi dengan pergerakan yang cepat dapat meningkatkan risiko terjadi benturan atau kecelakaan yang menyebabkan fraktur (Sagaran et al., 2017). Terdapat 15 subjek yang memiliki yang memiliki komorbid, diantaranya adalah hipertensi, diabetes melitus, aritmia, neuropati, dan osteoporosis. Sebagian besar subjek penelitian memiliki kondisi fisik yang baik yang ditunjukkan dengan American Society of Anesthesiology (ASA) score <3, satu orang pasien pada kelompok ceftriaxone memiliki ASA score 3. Lokasi fraktur terbanyak di kedua kelompok adalah fraktur radius.

\subsection{Gambaran penggunaan antibiotik profilaksis}

American Society of Health-System Pharmacists (ASHP), Infectious Diseases Society of America (IDSA), Surgical Infection Society (SIS), dan Society for Healthcare Epidemiology of America (SHEA) merekomendasikan cefazolin sebagai antibiotik profilaksis untuk operasi bedah ortopedi yang melibatkan pemasangan implan dengan dosis 2-3 gram untuk pasien dewasa dan $30 \mathrm{mg} / \mathrm{kg}$ berat badan untuk pasien anak-anak. Waktu yang paling optimal dalam pemberian antibiotik profilaksis direkomendasikan 60 menit sebelum insisi dan diberikan tidak lebih dari 24 jam (Singh et al., 2014).

Tabel 2. Karakteristik penggunaan antibiotik profilaksis pasien Open Reduction Internal Fixation (ORIF) fraktur tertutup di RS PKU Muhammadiyah Yogyakarta tahun 2020.

\begin{tabular}{|c|c|c|}
\hline Karakteristik antibiotik profilaksis & Cefazolin (\%) & Ceftriaxone $(\%)$ \\
\hline Antibiotik Profilaksis & 25 & 34 \\
\hline \multicolumn{3}{|l|}{ Dosis } \\
\hline 0,5 gram & $2(8)$ & 0 \\
\hline 1 gram & $4(16)$ & $22(64,7)$ \\
\hline 2 gram & $19(76)$ & $12(35,3)$ \\
\hline \multicolumn{3}{|l|}{ Waktu pemberian sebelum operasi } \\
\hline$\leq 60$ menit & $9(36)$ & $27(79,4)$ \\
\hline$>60$ menit & $16(64)$ & $7(20,6)$ \\
\hline \multicolumn{3}{|l|}{ Durasi pemberian } \\
\hline$\leq 24 \mathrm{jam}$ & $9(36)$ & $7(20,6)$ \\
\hline$>24$ jam & $16(64)$ & $27(79,4)$ \\
\hline
\end{tabular}

Data gambaran penggunaan antibiotik profilaksis pada penelitian ini disajikan pada Tabel 2. Subjek yang menggunakan antibiotik ceftriaxone pada penelitian ini lebih banyak dibandingkan dengan subjek yang menggunakan cefazolin. Dosis pemberian antibiotik profilaksis pada penelitian ini adalah 0,5 gram untuk pasien pediatrik dan 1 atau 2 gram untuk pasien dewasa dengan proporsi yang tidak jauh berbeda. Waktu pemberian antibiotik profilaksis 
paling banyak adalah $\leq 60$ menit dan diberikan $>24$ jam dan dilanjutkan dengan antibiotik profilaksis post operasi. Hasil yang sama ditemukan pada penelitian yang dilaksanakan pada tahun 2017 di Ethiopia dimana ceftriaxone paling banyak digunakan sebagai antibiotik profilaksis, yang diberikan tidak dalam 60 menit sebelum operasi dan diberikan selama >24 jam untuk semua jenis operasi termasuk ortopedi (Alemkere, 2018).

Penelitian sebelumnya yang dilakukan oleh Firdaus et al., (2020) yang mengevaluasi penggunaan antibiotik profilaksis pasien bedah ortopedi di Rumah Sakit Bangil menunjukkan bahwa antibiotk yang paling banyak digunakan adalah ceftriaxone dan cefuroxime. Hasil yang berbeda ditemukan pada penelitian yang dilakukan di Rumah Sakit Hasan Sadikin Bandung yang menunjukkan data bahwa antibiotik profilaksis yang banyak digunakan untuk tindakan ORIF adalah cefazolin yang diberikan hingga post operasi dan dilanjutkan antibiotik oral saat pulang (Edwiza et al., 2017). Dokter di rumah sakit tempat penelitian ini dilaksanakan banyak menggunakan ceftriaxone berdasar pada pengalaman empirik dan pertimbangan harga yang lebih murah sesuai dengan harga e-catalog.

\subsection{Efektivitas antibiotik pofilaksis}

Efektivitas antibiotik profilaksis pada penelitian ini dilihat dari angka kejadian infeksi daerah operasi (IDO) karena pemilihan antibiotik profilaksis yang tepat menurunkan risiko IDO (Alemkere, 2018). Kejadian IDO diambil dari penelusuran rekam medis pasien selama menjalani perawatan di rumah sakit, baik saat pasien rawat inap untuk menjalani operasi ORIF maupun saat pasien kontrol rawat jalan dalam kurun waktu 90 hari. Analisis perbedaan efektivitas kedua kelompok dilakukan dengan analisis bivariat menggunakan Fisher's exact test (Tabel 3).

Tabel 3. Perbandingan kejadian infeksi daerah operasi pasien Open Reduction Internal Fixation (ORIF) fraktur tertutup di RS PKU Muhammadiyah Yogyakarta tahun 2020.

\begin{tabular}{|c|c|c|c|c|}
\hline \multirow{2}{*}{$\begin{array}{l}\text { Antibiotik } \\
\text { Profilaksis }\end{array}$} & \multicolumn{2}{|c|}{ Jumlah Kejadian IDO } & \multirow{2}{*}{$\begin{array}{c}\text { Total } \\
(\mathbf{n}=59)\end{array}$} & \multirow{2}{*}{ P value } \\
\hline & IDO (\%) & Tidak IDO (\%) & & \\
\hline Cefazolin & 0 & $25(100)$ & 25 & 0,064 \\
\hline Ceftriaxone & $3(8,82 \%)$ & $31(91,18 \%)$ & 34 & \\
\hline
\end{tabular}

Angka kejadian IDO pada penelitian ini ditemukan sebesar 5,08\% dari total seluruh subjek atau 8,82\% (3 dari 34) dari pada pasien yang diberikan ceftriaxone dan $0 \%$ pada pasien yang diberikan cefazolin. Analisis perbedaan probabilitas kejadian IDO antara dua kelompok dilakukan uji bivariat dengan Fisher's Exact Test. Hasil analisis di antara keduanya tidak berbeda bermakna $(\mathrm{RR}=1,097 ; 95 \% \mathrm{CI}=0,988-1,218 ; \mathrm{p}=0,064)$.

Penelitian clinical trial yang dilakukan oleh Kalawar et al., (2018) di sebuah rumah sakit di India yang membandingkan pemberian cefazolin dan ceftriaxone yang dikombinasikan dengan gentamisin sebagai antibiotik profilaksis bedah ortopedi menunjukkan hasil angka 
kejadian IDO pada kelompok cefazolin sebesar 9\% dan kelompok ceftriaxone sebesar 3,1\%. Efektivitas kedua antibiotik tersebut secara statistik dinilai tidak berbeda signifikan. Begitu juga penelitian yang membandingkan antara cefazolin dan ceftriaxone sebagai antibiotik profilaksis pada operasi histerektomi juga menunjukkan bahwa tidak ada perbedaan yang signifikan antara cefazolin dan ceftriaxone dalam mencegah kejadian IDO (Phoolcharoen et al., 2012). Ceftriaxone dibandingkan selalosporin lain sebagai antibiotik profilaksis kolesitektomi juga tidak berbeda siginfikan dalam mencegah IDO (Lim et al., 2017). Meskipun demikian, antibiotik golongan sefalosporin generasi tiga seperti cefotaxime, cefoperazone, ceftriaxone, ceftazidime dan ceftizoxime serta generasi ke empat seperti cefepime tidak direkomendasikan oleh berbagai panduan untuk digunakan sebagai antibiotik profilaksis. Hal ini dikarenakan obatobat tersebut sebagian memiliki harga yang lebih mahal dan aktivitasnya lebih rendah dibanding cefazolin dalam menghambat pertumbuhan Staphylococci. Menurut WHO (2016), bakteri paling banyak $(30,4 \%)$ ditemukan sebagai penyebab IDO adalah Staphylococcus aureus yang merupakan flora normal di kulit. Sefalosporin generasi tiga dan empat memiliki aktivitas terhadap bakteri gram negatif yang lebih kuat sehingga diharapkan fokus digunakan sebagai antibiotik terapi (Geroulanos, et al., 2001).

\subsection{Keamanan antibiotik profilaksis}

Sefalosporin merupakan antibiotik yang banyak diberikan karena memiliki risiko menimbulkan alergi yang relatif kecil. Pada penelitian ini kemanan penggunaan cefazolin dan ceftriaxone dinyatakan sama. Tidak ditemukan kejadian efek samping baik pada kelompok subjek yang diberikan cefazolin maupun ceftriaxone.

\subsection{Faktor risiko IDO}

Hubungan antara kejadian IDO dengan faktor risiko dianalisis dengan analisis bivariat menggunakan Fisher's exact test dan tersaji pada Tabel 4. Faktor yang dikaji hubungannya dengan kejadian IDO berjumlah 7 dan didapatkan satu faktor risiko yang memiliki hubungan bermakna dengan variabel tergantung dalam penelitian ini $(\mathrm{p} \leq 0,25)$, yaitu durasi operasi. Namun setelah dilanjutkan dengan analisis regresi linear, maka durasi operasi tidak terdapat hubungan yang bermakna dengan kejadian IDO ( $p>0,05)$. Oleh karena itu, dalam panelitian ini dapat dikatakan bahwa kejadian IDO pasien dipengaruhi oleh faktor pemilihan antibiotik profilaksis, bukan karena faktor risiko yang lain.

Jumlah sampel yang sedikit dan ketersediaan data yang kurang lengkap menjadi keterbatasan dalam penelitian ini. Harus dipertimbangkan kondisi di masing-masing rumah sakit apabila akan menggunakan hasil penelitian ini menjadi acuan praktik klinis. Peneliti menyarankan untuk dilakukan penelitian lebih lanjut dengan jumlah sampel yang lebih banyak, 
di berbagai rumah sakit, dan pengambilan data secara prospektif sehingga dapat diketahui efektivitas maupun keamanan cefazolin dibandingkan ceftriaxone secara umum. Penelitian selanjutnya juga dapat dilakukan untuk membandingkan keduanya dalam efektivitas biayanya.

Tabel 4. Faktor risiko infeksi daerah operasi pasien Open Reduction Internal Fixation (ORIF) fraktur tertutup di RS PKU Muhammadiyah Yogyakarta tahun 2020.

\begin{tabular}{|c|c|c|c|c|}
\hline Faktor Risiko & Total Subjek & $\begin{array}{l}\text { IDO } \\
n=3\end{array}$ & $\begin{array}{c}\text { Tidak IDO } \\
n=56\end{array}$ & $P$ value \\
\hline Jenis Kelamin & & & & 0,112 \\
\hline Laki-laki & 30 & 0 & 30 & \\
\hline Perempuan & 29 & 3 & 26 & \\
\hline Usia & & & & 1,000 \\
\hline$<18$ tahun & 7 & 0 & 7 & \\
\hline $18-59$ tahun & 38 & 2 & 36 & \\
\hline$>60$ tahun & 14 & 1 & 13 & \\
\hline Komorbiditas & & & & 1,000 \\
\hline Ada & 10 & 0 & 10 & \\
\hline Tidak ada & 49 & 3 & 46 & \\
\hline Skor ASA & & & & 1,000 \\
\hline$<3$ & 58 & 3 & 55 & \\
\hline$\geq 3$ & 1 & 0 & 1 & \\
\hline Durasi Operasi & & & & 0,102 \\
\hline$\leq 60$ menit & 47 & 1 & 46 & \\
\hline$>60$ menit & 12 & 2 & 10 & \\
\hline Waktu Pemberian Profilaksis & & & & 0,274 \\
\hline$\leq 60$ menit & 36 & 3 & 33 & \\
\hline$>60$ menit & 23 & 0 & 23 & \\
\hline Lama Rawat Inap Preoperasi & & & & 1,000 \\
\hline$<3$ hari & 58 & 3 & 55 & \\
\hline$>3$ hari & 1 & 0 & 1 & \\
\hline
\end{tabular}

\section{Kesimpulan}

Pada penelitian ini ditunjukkan bahwa angka kejadian IDO pada pasien yang menjalani ORIF fraktur tertutup sebesar 5,08\% dari total subjek atau 8,82\% (3 dari 34) dari pasien yang diberikan ceftriaxone dan $0 \%$ pada pasien yang diberikan cefazolin. Perbedaan probabilitas kejadian IDO pada pemberian ceftriaxone sebagai antibiotik profilaksis tidak berbeda bermakna dengan pemberian cefazolin $(\mathrm{RR}=1,097 ; 95 \% \mathrm{CI}=0,988-1,218 ; \mathrm{p}=0,064)$. Keamanan kedua obat tersebut juga tidak berbeda.

\section{Ucapan Terimakasih}

Penulis mengucapkan terima kasih kepada berbagai pihak yang terlibat dalam penelitian yaitu Fakultas Farmasi UGM dan RS PKU Muhammadiyah Yogyakarta. Seluruh penulis tidak memiliki konflik kepentingan terhadap instansi yang terlibat dalam penelitian.

\section{Deklarasi Konflik Kepentingan}

Semua penulis menyatakan tidak ada konflik kepentingan terhadap naskah ini. 


\section{Daftar Pustaka}

Alemkere, G. (2018). Antibiotic usage in surgical prophylaxis: A prospective observational study in the surgical ward of Nekemte referral hospital. PLOS ONE, 13(9), e0203523. https://doi.org/10.1371/journal.pone.0203523.

Al-Mulhim, F. A., Baragbah, M. A., Sadat-Ali, M., Alomran, A. S., dan Azam, M. Q. (2014). Prevalence of Surgical Site Infection in Orthopedic Surgery: A 5-year Analysis. International Surgery, 99(3), 264-268. https://doi.org/10.9738/INTSURG-D-1300251.1.

Bandalović, A., Zindović, A., Boschi, V., Bakota, B., Marinović, M., Čoklo, M., Rošin, M., Parać, Z., dan Čukelj, F. (2015). A retrospective study of antibiotic prophylaxis value in surgical treatment of lower limb fracture. Injury, 46, S67-S72. https://doi.org/10.1016/j.injury.2015.10.038.

Bergh, C. (2021). Aspects of bone quality and risk assessments in fracture and elective orthopaedic patients. Gothenburg : University of Gothenburg.

Edwiza, D. S., Husen, I. R., dan Arsa, W. (2017). Prophylactic Antibiotic Pattern in Open Reduction Internal Fixation for Closed Fractures at Dr. Hasan Sadikin General Hospital Bandung in 2013. Althea Medical Journal, 4(3), 413-419. http://dx.doi.org/10.15850/amj.v4n3.1191.

Firdaus, Y. V., Jaelani, A. K., Herawati, F., dan Yulia, R. (2021). Evaluasi penggunaan antibiotik profilaksis pada pasien bedah ortopedi di Rumah Sakit Bangil. Intisari Sains Medis, 12(2), 407-414.

Gans, I., Jain, A., Sirisreetreerux, N., Haut, E. R., dan Hasenboehler, E. A. (2017). Current practice of antibiotic prophylaxis for surgical fixation of closed long bone fractures: A survey of 297 members of the Orthopaedic Trauma Association. Patient Safety in Surgery, 11(1), 2. https://doi.org/10.1186/s13037-016-0118-5.

Geroulanos, S., Marathias, K., Kriaras, J., dan Kadas, B., (2001). Cephalosporins in Surgical Prophylaxis. Journal of Chemotherapy, 13: 23-26.

Girard, R., Perraud, M., Herriot, H. E., Prüss, A., Savey, A., Tikhomirov, E., Thuriaux, M., Vanhems, P., dan Bernard, U. C. (2002). "Prevention of Hospital-Acquired Infections" A Practical Guide (2nd ed.). Geneva, Switzerland : World Health Organization.

Kalawar, R. P. S., Shrestha, B., Khanal, G., Chaudhary, P., Rijal, R., Maharjan, R., dan Paneru, S. (2018). Randomized controlled trial comparing cefazolin with ceftriaxone in perioperative prophylaxis in orthopaedic surgeries. Journal of BP Koirala Institute of Health Sciences, 1(1), 36-43. https://doi.org/10.3126/jbpkihs.v1i1.19752.

Li, G., Guo, F., Ou, Y., Dong, G., dan Zhou, W. (2013). Epidemiology and outcomes of surgical site infections following orthopedic surgery. American Journal of Infection Control, 41(12), 1268-1271. https://doi.org/10.1016/j.ajic.2013.03.305.

Lim, A., Prasetyo, S.A., dan Hapsari, R., (2017). Perbandingan Pemberian Antibiotik Profilaksis Ceftriaxon Dan Non-Ceftriaxon Terhadap Kejadian Surgical Site Infection Pasca Kolesistektomi. Jurnal Kedokteran Diponegoro, 6: 9.

Najjar, P. A., dan Smink, D. S. (2015). Prophylactic Antibiotics and Prevention of Surgical Site Infections. Surgical Clinics of North America, 95(2), 269-283. https://doi.org/10.1016/j.suc.2014.11.006.

Phoolcharoen, N., Nilgate, S., Rattanapuntamanee, O., Limpongsanurak, S., dan Chaithongwongwatthana, S. (2012). A randomized controlled trial comparing ceftriaxone with cefazolin for antibiotic prophylaxis in abdominal hysterectomy. International Journal of Gynecology \& Obstetrics, 119(1), 11-13. https://doi.org/10.1016/j.ijgo.2012.04.023.

Radji, M., Aini, F., dan Fauziyah, S. (2014). Evaluation of antibiotic prophylaxis administration at the orthopedic surgery clinic of tertiary hospital in Jakarta, Indonesia. Asian Pacific 
Journal of Tropical Disease, 4(3), 190-193. https://doi.org/10.1016/S22221808(14)60503-X.

Sagaran, V. C., Manjas, M., dan Rasyid, R. (2017). Distribusi Fraktur Femur Yang Dirawat Di Rumah Sakit Dr.M.Djamil, Padang (2010-2012). Jurnal Kesehatan Andalas, 6(3), 586589.

Singh, R., Singla, P., dan Chaudhary, U. (2014). Surgical Site Infections: Classification, Risk factors, Pathogenesis and Preventive Management. International Journal of Pharma Research and Health Sciences, 2(3), 203-214.

Trampuz, A., dan Widmer, A. F. (2006). Infections associated with orthopedic implants: Current Opinion in Infectious Diseases, 19(4), 349-356. https://doi.org/10.1097/01.qco.0000235161.85925.e8.

WHO. (2016). Global guidelines for the prevention of surgical site infection. Torino : World Health Organization.

\section{(c) (1) (0) \\ BY SA}

(C) 2021 by the authors. Submitted for possible open access publication under the terms and conditions of the Creative Commons Attribution-ShareAlike 4.0 International (CC BY-SA 4.0) license (https://creativecommons.org/licenses/by-sa/4.0/). 